\title{
PENGARUH PELATIHAN SELF-REGULATED LEARNING TERHADAP PROKRASTINASI PENYELESAIAN SKRIPSI PADA MAHASISWA TINGKAT AKHIR
}

\author{
Dewita Karema Sarajar \\ Magister Psikologi Profesi Universitas Mercu Buana Yogyakarta \\ dewita@gmail.com
}

\begin{abstract}
Abstrak
Prokrastinasi dapat terjadi pada mahasiswa terutama pada penyelesaian tugas akhir atau skripsi. Prokrastinasi adalah perilaku yang merugikan individu terkait dengan rendahnya kemampuan untuk meregulasi diri sendiri. Kemampuan regulasi diri dikenal dengan self-regulated learning yaitu proses mengaktifkan kemampuan kognisi, afeksi dan perilaku untuk menunjang proses pencapaian tujuan belajar. Penelitian ini menguji pengaruh self-regulated learning, yang diberikan dalam bentuk pelatihan, pada prokrastinasi penyelesaian skripsi mahasiswa. Penelitian ini melibatkan 18 orang mahasiswa yang telah mengerjakan skripsi selama 2 semester lebih. Skala prokrastinasi penyelesaian skripsi digunakan untuk mengumpulkan data. Hasil penelitian dengan analisis statistik Uji-t dengan independent sample t-test $(\alpha=5 \%)$ menggunakan skor post-test kelompok eksperimen dan kelompok kontrol, menunjukkan nilai tsebesar $=2.189$ dengan $\mathrm{p}=0.04$ $(\mathrm{p}<0,05)$ sehingga dapat dikatakan bahwa ada perbedaan skor post-test antara KE dan KK, dimana skor KE lebih rendah dibandingkan skor KK. Kelompok yang mendapat pelatihan selfregulated learning menunjukkan penurunan prokrastinasi dibandingkan kelompok yang tidak mendapat pelatihan self-regulated learning.
\end{abstract}

Kata kunci : self-regulated learning, prokrastinasi, skripsi

\section{THE EFFECT OF SELF-REGULATED LEARNING TRAINING ON PROCRASTINATION OF THESIS COMPLETION ON FINAL YEAR STUDENTS}

\author{
Abstract \\ Dewita Karema Sarajar \\ Magister Psikologi Profesi Universitas Mercu Buana Yogyakarta \\ dewita@gmail.com
}

\begin{abstract}
Procrastination can occur in the students especially on the completion of the final project or thesis. Procrastination is a behavior that harms the individual associated with the low ability to self-regulate. Self regulation capability or known as self-regulated learning, is the process of activating the ability of cognition, affection and behavior to support the process of achieving learning goals. This study examines the influence of self-regulated learning, which is given in the form of training, on the procrastination of student thesis completion. This research involves 18 students who have been working on thesis for more than 2 semesters. Prokrastination of thesis completion scale is used to collect the data. Result of the research with t-test statistic analysis with independent sample t-test $(\alpha=5 \%)$ using post-test score of experimental group and control group, showed $\mathrm{t}$ value $=2,189$ with $\mathrm{p}=0.04(\mathrm{p}<0,05)$ It can be said that there is difference of post-test score between $\mathrm{KE}$ and $\mathrm{KK}$, where KE score is lower than KK score. Groups that received selfregulated learning training showed a decrease in procrastination compared to those who did not receive self-regulated learning training.
\end{abstract}

Keywords: self-regulated learning, procrastination, thesis 


\section{PENDAHULUAN}

Skripsi merupakan suatu syarat yang harus dipenuhi oleh mahasiswa untuk menentukan layak tidaknya mereka mendapatkan gelar kesarjanaan S-1. Begitu panjang dan rumitnya proses pengerjaan skripsi ini sehingga membutuhkan biaya, tenaga, waktu, dan perhatian yang tidak sedikit. Umumnya, mahasiswa diberikan waktu untuk menyelesaikan skripsi dalam jangka waktu satu semester atau kurang lebih sekitar enam bulan. Tetapi pada kenyataanya, banyak mahasiswa yang memerlukan waktu lebih dari enam bulan untuk mengerjakan skripsi (Darmono dan Hasan, 2005). Mahasiswa yang tidak dapat menyelesaikan skripsinya dalam waktu yang ditentukan kemudian mengalami keterlambatan kelulusan karena pengerjaan skripsi yang tidak selesai.

Salah satu penyebab mengapa skripsi mahasiswa tidak selesai dalam waktu yang ditentukan adalah karena adanya ketidakdisiplinan dan penundaan dalam mengerjakan skripsi. Solomon \& Rothblum (1984) menyatakan beberapa penelitian tentang perilaku tidak disiplin waktu, yang dalam literatur ilmiah psikologi disebut dengan prokrastinasi (procrastination), menjadi masalah substansial pada mahasiswa. Prokrastinasi adalah suatu kecenderungan untuk menunda dalam memulai maupun menyelesaikan kinerja secara keseluruhan untuk melakukan aktivitaslain yang tidak berguna, sehingga kinerja menjadi terhambat, tidak pernah menyelesaikan tugas tepat waktu, serta sering terlambat dalam menghadiri pertemuan-pertemuan (Solomon dan
Rothblum 1984). Prokrastinasi dalam menyelesaikan skripsi adalah kecenderungan menunda-nunda untuk memulai atau menyelesaikan karya tulis sebagai syarat untuk mendapatkan gelar sarjana. Definisi prokstinasi secara umum dipahami sebagai hal yang dilakukan secara sadar.

Prokrastinasi memberikan banyak kerugian terhadap pelakunya, baik kerugian materiil maupun immateriil (Fibrianti, 2009; Muhid, 2009; Siaputra, Prawitasari, Hastjarjo, Azwar, 2011; Steel, 2007; Tanriady, 2009; Utomo, 2010). Menurut Ferrari dan Morales (2007) prokrastinasi pengerjaan skripsi memberikan dampak yang negatif bagi para mahasiswa, yaitu banyaknya waktu yang terbuang tanpa menghasilkan sesuatu yang berguna. Prokrastinasi juga dapat menyebabkan penurunan produktivitas dan etos kerja individu sehingga membuat kualitas individu menjadi rendah (Mastuti, 2010).

Lay (dalam Wolters, 2003) mengemukakan bahwa prokrastinasi berhubungan dengan berbagai fungsi kognitif, afektif dan motivasional pada mahasiswa, dimana fungsi kognitif berkaitan dengan kemampuan memahami tujuan dan usaha yang perlu dilakukan, fungsi afeksi berkaitan dengan keyakinan untuk dapat menyelesaikan skripsi, dan fungsi motivasional berkaitan dengan keinginan untuk menyelesaikan skripsi. Ditambahkan Lay (dalam Wolters, 2003) saat ketiga fungsi kognitif ini bermasalah, maka perilaku prokrastinasi dapat muncul yang ditandai dengan keengganan untuk menyelesaikan tugas, dalam hal ini berupa tugas akhir perkuliahan atau skripsi. 
Keengganan yang diikuti penundaan pengerjaan tugas ini dapat dikurangi dengan suatu kondisi dimana mahasiswa tersebut harus dapat mengaktifkan dan mengendalikan metakognitif, motivasi, dan perilaku dalam belajarnya yang secara sistematis berorientasi pada pencapaian tujuan, yang dikenal dengan istilahself regulated learning, guna mendorong untuk mengerjakan tugas-tugas akademik yang seharusnya dikerjakan.

$$
\text { Self-regulated learning (SRL), }
$$

dikembangkan dalam bentuk pelatihan sebagai treatment untuk mengatasi masalah prokrastinasi penyelesaian skripsi pada mahassiswa. Menurut peneliti, mahasiswa yang melakukan prokrastinasi dalam penyelesaian skripsi perlu diberikan pelatihan self regulated learningsehingga dapat lebih mengatur waktu dan usahanya untuk mencapai tujuan penyelesaian skripsi. Pandangan tersebut berdasar pada hasil penelitian yang menunjukkan bahwa bahwaprokrastinasi dari seseorang dipengaruhi oleh kurangnya kemampuan untuk menetapkan aturan bagi dirinya sendiri dan menjalankannya, sehingga perlu diberi metode intervensi berupa pelatihan mengenai bagaimana melakukan regulasi diri (Vahedi, Mostatafi, \&Mortazanajad, 2009).

Pemberian pelatihan self regulated learningdianggap penting dengan asumsi bila seseorang dalam mengelola waktu dan usahanya sangat baik maka tujuan (menyelesaikan skripsi) yang diinginkannya dapat tercapai. Rumusan masalah dalam penelitian ini adalah untuk mengetahui apakah penerapan Self-Regulated Learning dapat mengurangi prokrastinasi akademik pada mahasiswa yang sedang mengerjakan skripsi?

\section{METODE}

Pada penelitian ini jenis penelitian yang digunakan adalah eksperimental dan desain penelitiannya adalah Desain eksperimental dalam penelitian ini menggunakan desain duakelompok yaitu Pretest-Posttest Control Group Design. Subjek dalam penelitian ini adalah mahasiswa yang sedang mengerjakan skripsi di Universitas Swasta yang ada di Salatiga. Subjek penelitian akan dibagi dalam 2 kelompok, yaitu kelompok eksperimen dan kelompok kontrol. Kelompok eksperimen adalah kelompok yang mendapatkan perlakuan berupa pemberian pelatihan Self-Regulated Learningdalam pelaksanaan penelitian dan sekaligus diberikan pretest maupun posttest. Kelompok kontrol adalah adalah kelompok yang tidak mendapatkan perlakuan (tidak mengikuti pelatihan Self-Regulated Learning)dalam pelaksanaan penelitian tetapi diberikan pre-test dan post-test).Adapun karakteristiksubjek penelitian adalah sebagai berikut :

a. Mahasiswa yang masih aktif (tidak dalam masa cuti)

b. Mahasiswa yang sudah mengerjakan skripsi lebih dari 2 semester

c. Mahasiswa dengan kategori skor sedang, tinggi atau sangat tinggi pada skala prokrastinasi penyelesaian skripsi

Untuk mendapatkan gambaran mengenai prokrastinasi penyelesaian skripsimahasiswa tingkat akhir, maka pengambilan data dilakukan dengan 
menggunakan skala prokrastinasi penyelesaian skripsi. Adapun indikator yang digunakan mengacu pada indikator prokrastinasi menurut Schouwenburgyaitu :(a) Suka menunda, (b) Lamban dalam menyelesaikan skripsi, (c)Adanya kesenjangan waktu dalam menyelesaikan skripsi, (d)Melakukan aktivitas lain yang lebih menyenangkan dari pada menyelesaikan skripsi.

Skala prokrastinasi penyelesaian skripsi terdiri item sebanyak 40 item, dan alat ukur ini telah diujicobakan pada 50 orang mahasiswa Universitas swasta di Salatiga yang sedang mengerjakan skripsi. Berdasarkan hasil perhitungan uji validitas item total correlation dengan menggunakan metode korelasi Pearson Product Moment pada skala prokrastinasi penyelesaian skripsi yang digunakan untuk uji coba, diperoleh hasil bahwa dari 40 item yang telah diuji terdapat 6 item yang gugur, karena memiliki nilai koefisien korelasi yang $\leq$ 0,3 (Azwar, 2008), sehingga item yang valid berjumlah 34 item.Reliabilitas skala prokrastinasi penyelesaian skripsi diukur dengan menggunakan teknik Alpha Cronbach dengan bantuan SPSS 17.0 for windows, mendapatkan hasil $\alpha=0.939$, berarti reliabilitas skala prokrastinasi penyelesaian skripsi adalah tinggi. Skala yang valid akan dijadikan pre-test dan post-test pada kedua kelompok penelitian. Adapun tahap-tahap dalam penelitian ini adalah sebagai berikut :

1. Tahap pembuatan skala dan uji coba skala

2. Tahap pembuatan modul dan uji coba modul

3. Tahap seleksi subjek
4. Tahap pelaksanaan penelitian

5. Tahap analisis hasil penelitian

\section{HASIL DAN PEMBAHASAN}

Berdasarkan analisis statistik Uji-t dengan independent sample t-test $(\alpha=5 \%)$ menggunakan skor post-test kelompok eksperimen dan kelompok kontrol, didapatkan nilai tsebesar $=2.189$ dengan $\mathrm{p}=0.04(\mathrm{p}<$ 0,05) sehingga dapat dikatakan bahwa ada perbedaan skor post-test antara KE dan KK, dimana skor KE lebih rendah dibandingkan skor KK. Hasil ini didukung dengan nilai ratarata skor post-test $\mathrm{KE}$ yang menunjukkan angka 85,78 (menunjukkan kategori skor prokrastinasi rendah) dan post-test $\mathrm{KK}$ yang menunjukkan angka 101,22 (menunjukkan kategori skor prokrastinasi sedang).

Bila dibandingkan perubahan skor, dalam hal ini penurunan skor prokrastinasi penyelesaian skripsi, kelompok eksperimen dan kelompok kontrol menampakkan perubahan yang berbeda. Pada kelompok eksperimen, dapat dilihat bahwa pada pre-test, rata-rata skor subjek adalah 106,44 dan pada post-test, ratarata skor turun menjadi 85,78 . Bila dirataratakan dapat dilihat bahwa penurunan skor kelompok eksperimen sebanyak 20,66 poin. Sementara dibandingkan dengan skor kelompok kontrol, pada pre-test menunjukkan rata-rata skor 98,56 dan pada post-test menunjukkan kenaikan skor rata-rata menjadi 101,22 Meskipun kurang signifikan, namun kelompok kontrol mengalami kenaikan skor rata-rata prokrastinasi penyelesaian skripsi sebanyak 2,66 poin. Dari perbandingan ratarata skor dan perubahan skor yang ditunjukkan 
maka dapat dikatakan bahwa kelompok subjek yang diberikan pelatihan Self-Regulated Learning menunjukkan penurunan prokrastinasi penyelesaian skripsi, sementara kelompok yang tidak diberikan pelatihan SelfRegulated Learning tidak menunjukkan penurunan prokrastinasi penyelesaian skripsi.

Bila dilihat dari penyebab prokrastinasi penyelesaian skripsi dan dikaitkan dengan unsur-unsur dalam pelatihanself-regulated learning, maka dapat dilihat bagaimana pelatihan self-regulated learning dapat berpengaruh pada penurunan perilaku prokrastinasi. Berikut dapat dilihat dalam tabel di bawah ini :

Tabel 1. Hubungan Indikator Prokrastinasi dan Unsur Self-Regulated Learning
(1)

Sasaran dalam pelatihan

Self-Regulated Learning

a. Mampu menentukan tujuan dan rencana

b. Mampu melakukan pemantauan diri berkaitan dengan kemampuan diri dan keadan lingkungan

c. Mampu melakukan kontrol diri, mengatasi godaan dari luar diri

d. Mampu melakukan evaluasi diri berkaitan dengan usaha yang dilakukan
Indikator Prokrastinasi

\section{(2)}

a. Penundaan untuk memulai maupun menyelesaikan kerja pada tugas yang dihadapi

b. Keterlambatan dalam mengerjakan tugas

c. Kesenjangan antara rencana dan kinerja aktual

d. Melakukan aktifitas lain yang lebih menyenangkan dari pada melakukan tugasyang harus dikerjakan
Unsur yang terdapat dalam pelatihan self-regulated learning yyang kemudian dikembangkan menjadi sasaran dalam pelatihan. Sasaran ini menjadi cara untuk mengatasi permasalahan prokrastinasi, berkaitan dengan indikator perilaku prokrastinasi. Sasaran yang pertama berkaitan dengan tujuan dan rencana. Seorang prokrastinator dalam penyelesaian skripsi bermasalah pada tidak adanya tujuan yang ditentukan dan tidak adanya rencana untuk melakukan usaha mencapai tujuan akademik yang seharusnya dicapai. Dalam pelatihan selfregulated learningpeserta mendapat pemahaman secara kognitif mengenai bagaimana membuat tujuan yang efektif dan bagaimana merancang rencana untuk pencapaiannya. Tidak hanya itu, subjek juga diberi kesempatan merancang sendiri tujuan dan rencana untuk penyelesaian skripsi, sehingga usaha yang dilakukan lebih nyata. Subjek menjadi belajar untuk menjadikan penyelesaian skripsi sebagai prioritas, karena penetapan tujuan berkaitan dengan prioritas, seperti menurut Lakein (1997) jika individu memiliki tujuan tertentu, maka ia akan cenderung menjadikan tujuannya sebagai prioritas dibanding hal lainnya. Dengan memiliki tujuan dan rencana, individu akan belajar untuk merancang rencana kerja dan berusaha memenuhinya serta akan menjadikan penyelesaian skripsi sebagai kegiatan utama untuk dilakukan dibanding kegiatan lainnya (Bernard, 1991). Dengan demikian, unsur penetapan tujuan (1a) dalam self-regulated learning dapat mengintervensi indikator prokrastinasi penyelesaian skripsi, yaitu berkaitan dengan rencana kerja (2c) dan penentuan prioritas kegiatan penyelesaian skripsi (2d). 
Selain penentuan tujuan yang bermasalah, perilaku prokrastinasi sedikit banyak memang dipengaruhi oleh lingkungan individu, dalam hal ini berkaitan dengan faktor eksternal, yaitu lingkungan tempat individu berkuliah. Dari subjek diketahui bahwa beberapa penghambat yang berasal dari luar diri mereka, yakni tuntutan orang tua yang membuat tertekan, lingkungan tempat tinggal atau teman yang kurang mendukung untuk menyelesaikan skripsi dan dosen yang dirasa menghambat atau susah ditemui. Hal seperti ini menjadi tantangan bagi individu yang menyelesaikan skripsi. Dalam pelatihan selfregulated learning subjek mendapat kesempatan belajar bagaimana memonitor halhal di luar diri dan di dalam diri yang dapat mendukung penyelesaian skripsinya, dalam hal ini berkaitan dengan bagaimana melakukan monitoring diri. Monitoring diri (Selfmonitoring) diperlukan oleh seorang individu agar individu yang bersangkutan dapat menunjukkan performance yang sesuai dengan lingkungan di sekitarnya,termasuk di lingkungan akademik (Snyder dalam Baron \& Byrne, 1994).

Ditambahkan Baron \& Byrne(1994)individu dengan self monitoring yang tinggi memiliki kepercayaan diriyang tinggi dalam menghadapi segala hambatan yang terjadi.Hal ini juga berkaitan dengan bagaimana individu mengerahkan usahanya sesuai dengan tujuan yang sudah dibuat.Dengan melakukan monitoring diri, individu akan mengusahakan dirinya untuk tidak menunda pekerjaan dan menyelesaikan tugasnya tepat waktu (Green, 1982). Dapat dikatakan bahwa unsur monitoring diri (1b) dapat mengintervensi perilaku prokrastinasi dalam indikator penundaan untuk memulai dan menyelesaikan tugas (2c) serta keterlambatan dalam menyelesaikan tugas (2d).

Selain dengan monitoring atau pemantauan diri, seorang prokrastinator juga bermasalah dengan kontrol diri (1c). Muhid (2009) menemukan dalam sebuah penelitian mengenai aspek-aspekpada diri individu yang mempengaruhiseseorang untuk mempunyai suatu kecenderungan perilaku prokrastinasi, antaralain rendahnya kontrol diri (self control), self-consciuous, rendahnya self esteem, selfefficacy, dan kecemasan sosial. Kontrol diri yang bermasalah berkaitan dengan sulitnya menolak ajakan teman untuk bersenangsenang daripada mengerjakan skripsi atau sulit menahan diri untuk menjauh dari kegiatan yang dapat menunda pengerjaan skripsi. Hal ini diintervensi lewat pelatihan Self-Regulated Learning, dimana salah satu unsurnya menyangkut bagaimana melakukan kontrol diri. Subjek diajarkan bagaimana menggunakan strategi untuk mengontrol diri terhadap hal-hal yang mengganggu penyelesaian skripsi, sebagai bagian dari melakukan regulasi diri yang baik. Dengan melakukan kontrol diri, individu mampu mengatur stimulus sehingga dapat menyesuaikan perilakunya kepada hal-hal yang lebih menunjang penyelesaian skripsinya (Aliya dan Iranita, 2011). Ditambahkan Aliya dan Iranita (2011) dengan kontrol diri, mahasiswa mampu mengatur stimulus sehingga dapat menyesuaikan perilakunya 
kepada hal-hal yang lebih menunjang penyelesaian skripsinya. Sehingga ia akan sesegera mungkin menyelesaikan skripsinya tanpa menunda - nundanya. Hal ini berkaitan dengan indikator prokrastinasi yaitu penundaan penyelesaian tugas (2a) dan melakukan aktivitas lain lebih menyenangkan (2d).

Unsur terakhir yang menjadi sasaran adalah evaluasi diri (1d). Menurut Ferrari (1995) untuk menemukancara terbaik dalam penyelesaian tugasperlu dilakukan evaluasi diri. Ditambahkan Ferrari, prokrastinasi dapat dipengaruhi oleh kemampuan mengevaluasi diri dari kebiasaan-kebiasaan buruk yang menghambat penyelesaian tugas. Individu yang ingin melepaskan diri dari kebiasaan menunda, perlu mengembangkan kemampuan mengevaluasi diri. Sebagai salah satu unsur dalam pelatihan Self-regulated learning, evaluasi diri menjadi bagian yang penting dalam hal melihat hal apa yang sudah dilakukan dan bagaimana keberhasilannya pada penyelesaian skripsi. Zimmerman dan Martinez-Pons (dalam Purdie, Hattie \& Douglas, 1996) dalam penyelesaian tugasnya, mahasiswa dapat menghindari penundaan dengan cara mengevaluasi diri berkaitan dengan kebiasaan-kebiasaan yang dilakukan dalam mengerjakan tugas akademik, dalam hal ini berkaitan dengan indikator prokrastinasi yaitu penundaan dalam menyelesaikan tugas (2a) danketerlambatan dalam menyelesaikan tugas (2b). Evaluasi diri membuat merekamengevaluasikan dirinya dengan mereflesikan kesalahan mereka dimana mahasiswatersebut dapat berinisiatif untuk menyelesaikan tugas akademiknya. Dengan mengembangkan kemampuan evaluasi diri, subjek yang mendapat pelatihan menjadi mengerti cara untuk melihat perubahan usaha yang dilakukan dengan hasil yang diperoleh.

Berdasarkan kaitan unsur dan indikator prokrastinasi diatas maka dapat dikatakan bahwa pelatihan Self-Regulated Learning dapat menurunkan perilaku prokrastinasi dari mahasiswa yang mengerjakan skripsi. Bila melihat dari segi metode penelitian, pelatihan Self-Regulated Learning telah diberikan dengan cukup efektif. Sebelum diberi pelatihan, subjek terlebih dahulu diberi pretest untuk mengukur baseline tingkat prokrastinasi mereka. Setelah mendapatkan baseline tingkat prokrastinasi subjek, barulah subjek diberi pelatihan Self-Regulated Learning dengan metode ceramah dan simulasi. Simulasi berarti, subjek diajak untuk melakukan praktek materi dengan membuat catatan harian selama 10 hari, mengenai usaha yang dilakukan untuk penyelesaian skripsi. Proses ini disebut tahap 'Train my self'. Dalam proses pelatihan ini, tidak hanya kognisi mengenai pengetahuan akanself-regulated learning dibentuk, tapi juga afeksi dan perilaku mereka dibentuk dengan pelaksanaan simulasi atau tahap 'Train my self'. Dalam proses ini, dilakukan kontrol untuk mengantisipasi dilakukannya faking oleh subjek, selain untuk mendorong subjek untuk benar-benar melakukan pencatatan dengan sungguh-sungguh sebagai usaha untuk membentuk Self-Regulated Learning mereka. Kontrol yang dilakukan berupa meminta tanda tangan dosen pembimbing di setiap hari 
pencatatan. Setelah 10 hari praktek materi terlaksana, barulah subjek diberi post-test untuk mengukur perubahan yang dicapai.

Dalam pencatatan harian yang dibuat oleh subjek eksperimen, ditemukan bahwa ke11 orang subjek melakukan pencatatan tentang usaha yang mereka lakukan selama 10 hari kegiatan praktek materi atau yang disebut tahap 'Train my self'. Secara kualitatif, peneliti menilai bahwa subjek dalam kelompok eksprimen telah melakukan usaha untuk mencapai tujuan yang sudah ditetapkan oleh mereka sendiri. Dari antara mereka ada yang akhirnya sudah bisa menyelesaikan angket untuk pengambilan data, ada yang sudah menyelesaikan skripsi sampai bab akhir dan siap ujian, ada juga yang menyelesaikan skripsi sampai bab 3. Kelompok subjek menilai sendiri kemajuan yang mereka alami dan perubahan apa yang dicapai dalam proses pelatihan ini. Meskipun mereka juga mengakui adanya perasaan malas yang melanda, namun mereka mampu mengalahkan rasa malas itu, dan berusaha mencapai perubahan dalam jangka waktu 10 hari.

Dalam proses pelatihan self-regulated learning, subjek telah melakukan observasi diri, keputusan diri dan refleksi diri. Observasi diri dalam self-regulated learning membuat individu belajar menilai perilaku mereka terhadap tujuan-tujuan ataustandarstandar yang telah disusun. Observasi diri yang dilakukan subjek barkaitan dengan penilaian akan perilaku yang sudah ditentukan untuk dilakukan. Sementara itu, keputusan diri berkaitan dengan bagaimana individu membandingkan performa yang dilakukan saat ini dengan tujuan yang sudah ditentukan, dalam hal ini melihat apakah perilaku yang dilakukan masih sesuai dengan target perilaku yang sudah ditentukan tidak, serta refleksi diri merupakan proses dimana individu menilai perilaku apa yang tepat untuk dilakukan selanjutnya. Menurut Zimmerman (2007) selfregulated learningberkenaan dengan prosesproses di mana pebelajar menggerakkan dan menyokong perilaku, kognisi, dan afeksi yangsecara sistematis berorientasi ke arah pencapaian tujuan belajar dimana prosesproses tersebut terdiri dari observasi diri, keputusan diri dan refleksi diri.

Dari hasil pemberian langkah-langkah dalam pelatihan Self-Regulated Learningtersebut di atas yang merupakan bagian dari penelitian ini, didapati bahwa terjadi penurunan prokrastinasi penyelesaian skripsi, dilihat dari kualitatif pencatatan harian subjek selain juga bisa dilihat dari hasil uji statistik yang dilakukan peneliti. Perlakuan seperti ini hanya diberi ke kelompok eksperimen, tidak diberi ke kelompok kontrol. Dengan pre-test dan post-test yang sama diberikan menunjukkan bahwa perubahan yang ditunjukkan kelompok eksperimen, tidak ditemukan pada kelompok kontrol, sehingga dapat menjadi penguat bahwa pelatihan yang diberikan betul efektif menurunkan perilaku prokrastinasi.

\section{KESIMPULAN}

Berdasarkan hasil penelitian dan pembahasan yang telah diuraikan sebelumnya, maka dapat ditarik kesimpulan bahwa pelatihan Self-Regulated Learning 
berpengaruh pada penurunan perilaku prokrastinasi penyelesaian skripsi. Hasil analisis data menunjukkan bahwa perilaku prokrastinasi penyelesaian skripsi mahasiswa tingkat akhir yang mendapat pelatihan SelfRegulated Learning mengalami penurunan dibandingkan subjek yang tidak mendapat pelatihan Self-Regulated Learning. Secara kuantitatif, dapat dikatakan bahwa ada perbedaan tingkat prokrastinasi mahasiswa yang mendapat pelatihan self-regulated learning dan mahasiswa yang tidak mendapat pelatihan self-regulated learning.

Bila dibandingkan perubahan skor, dalam hal ini penurunan skor prokrastinasi penyelesaian skripsi, kelompok eksperimen dan kelompok kontrol menampakkan perubahan yang berbeda. Pada kelompok eksperimen, dapat dilihat bahwa pada pre-test, rata-rata skor subjek adalah 106.44dan pada post-test, rata-rata skor turun menjadi 85.78 . Bila dirata-ratakan dapat dilihat bahwa penurunan skor kelompok eksperimen sebanyak 14,91 poin. Sementara dibandingkan dengan skor kelompok kontrol, pada pre-test menunjukkan rata-rata skor 98.56dan pada post-test menunjukkan kenaikan skor rata-rata menjadi 101.22. Meskipun kurang signifikan, namun kelompok kontrol mengalami kenaikan skor rata-rata prokrastinasi penyelesaian skripsi sebanyak 2,2 poin. Dari perbandingan rata-rata skor dan perubahan skor yang ditunjukkan maka dapat dikatakan bahwa kelompok subjek yang diberikan pelatihan Self-Regulated Learning menunjukkan penurunan prokrastinasi penyelesaian skripsi, sementara kelompok yang tidak diberikan pelatihan Self-Regulated Learning tidak menunjukkan penurunan prokrastinasi penyelesaian skripsi.

\section{DAFTAR PUSTAKA}

Anita, Woolfolk. (2004). Educational Psychology. Boston : Pearson Educational.

Aini, A.N., \& Mahardayani, I.H. (2011). Hubungan Antara Self-Regulated Learning Dengan Prokrastinasi DalamMenyelesaikan Skripsi Pada Mahasiswa Universitas Muria Kudus. Jurnal Psikologi Pitutur.Volume I, No. 2, Juni 2011.

Arikunto, S. (2006). Prosedur penelitian. Jakarta: PT. Rineka Cipta.

Azwar, S. (2008). Penyusunan skala psikologi. Yogyakarta: Pustaka Pelajar.

Cobb, R.,(2003). The relationship between self regulated learning behaviorsand academic perfomance in web-based courses. Dissertation : The Faculty of VirginiaPolytechnic Institute and State University

Darmono \& Hasan, A,. (2005). Menyelesaikan Skripsi dalam Satu Semester. Jakarta : PT. Grasindo.

Emida \& Florentina Y,. (2009). Penerapan Pelatihan Self-Regulated Learning untuk mengatasi prokrastinasi siswa SMA kelas XI. Tesis, tidak diterbitkan : Unika Widya Mandala Surabaya.

Ferrari, Josep R., Johnson, J. \& McCown, W.. (1995). Procrastination and Task Avoidance. New York, USA: Plenum Press.

Ferrari, J. R. \& Morales, J. F. D. (2007). Perceptions of Self-concept and Selfpresentation by Procrastinators: Further Evidence. Chicago. The Spanish Journal of Psychology. (http://psycnet.apa.org/journals/jid/30/3/ 163/ diunduh 3 Mei 2013). 
Green, L. (1982). Minority Students, Self Control of Procrastination, Journal of Counseling Psychology, 29, 636-644

Hidayat, Ahmad. (2013). Hubungan Regulasi Diri Dengan Prestasi Belajar Kalkulus, ditinjau dari Aspek Metakognisi, Motivasi Dan Perilaku. Jurnal Elektronik Pendidikan Matematika Tadulako, Volume 01 Nomor 01, September 2013.

Lativah, Eva. (2010). Strategi Self Regulated Learning dan Prestasi Belajar:Kajian Meta Analisis menemukan hubungan antara penerapan SRL dengan prestasi belajar. Jurnal Psikologi. Vol 37 no $6(2)$.

Lestari, H. \& Nanda.A,. (2011). Hubungan antara self-regulated learning dengan prokrastinasi penyelesaian skripsi pada mahasiswa fakultas sastra dan seni rupa UNS. Anima, Indonesian Psychological Journal, Vol. 15, No 5, 103-109.

Mastuti, E. (2009). Memahami Perilaku Prokrastinasi Akademik Berdasar Tingkat Self Regulation Learning. Universitas Airlangga. Jurnal Psikologi Indonesia.

Monks, F. J., Knoers, A. M. P. dan Haditono, S. R. (1999). Psikologi perkembangan Pengantar dalam Berbagai Bagiannya. Yogyakarta: Gajah Mada University Press.

Purdie, N., \& Douglas, G. (1996). Student conceptionof learning andtheir use of self regulated learning strategies : A cross-culturalcomparison. Journal of Educational Psychology, 88, 87-100.

Pychyl, A. T., Coplan, J. R. Dan Reid, A. M. P. (2001). Parenting and procrastination: gender differences in the relations between procrastination, parenting style and self-worth in early a do lescence. Canada. Journal of Personality and Individual

Differences. (http://users.ugent.be/ wbeyers/scripties 2012/artikels/Pychyl\%20et\%2l. 2001.pdf diunduh 17 Desember 2014).
Romano, J.L. (1996). Theoretical Concept Treatment of Procrastination. ContemporaryPsychology. 4, 698-699.

Rumini, Sri. (2006). Psikologi Pendidikan. FIP IKIP Yogyakarta: UPP IKIPYogyakarta

Savira. F., \& Suharsono, Y. (2013). Self Regulated Learning (SRL) denganProkrastinasi Akademik pada Siswa Akselerasi. Jurnal Ilmiah PsikologiTerapan, vol 01, No 01. Fakultas Psikologi. Malang: UniversitasMuhammadiyah Malang.

Schouwenburg, C.H \& Dewitte. S. (1995). Procrastination, Temptations, and Incentives:The Struggle between the Present and the Future in Procrastinators and the Punctual. European Journal of Personality.

(http://www.econ.kuleuven.be/public/nd bad99/papers\%20blog/BEFORE1993/D ewite\%20Schouwenburg\%20EJP\%1995 $\% 20$ procrastination $\% 20$ present $\% 20$ fut ure.pdf. diunduh 17 Desember 2014).

Solomon, L.J.\& Rothblum, E.D. (1984). Academic Procrastination: Frequency andCognitive-Behavioral Correlates, Journal of Counseling Psychology, 31,504-510.

Slavin, R.E. (2007). What works? Issues in synthesizing educational program evaluations. Baltimore, MD: Center for Data-Driven Reform in Education, Johns Hopkins University.Steel, P. (2007). The Nature of Procrastination : A Meta-Analytic and Theorical Review of Quintessential Self Regulatory Failure. Psychological Bulletin. 133 (1). $65-94$.

Tondok, M. S., Ristyadi, H. dan Kartika, A. (2008). Prokrastinasi Akademik dan Niat Membeli Skripsi. Surabaya. Indonesian Psychological Journal. (http://anima.ubaya.ac.id/class/openpdf. 
php?file=1371800994.pdf diunduh 17 Desember 2014.

Vahedi, S., Mostafafi, F., \& Mortazanajad, H. (2009). Self-regulated learning and dimensionsof parenting styles predict psychological procrastination of undergraduatestudents. Iran Journal of Psychiatry, 4, 147-154.

Wolter, Christopher. (2003). Undertanding Procrastination from a Self-Regulation Learning Perspective. Dissertation : University of Houston.

Zimmerman, B. J. (1989). A social cognitive view of self-regulated academic learning. Journal of Educational Psychology, 81, 329-339.

Zimmerman, B. J., \& Martinez-Pons, M. (1988). Construct validation of a strategy model of a student selfregulated learning. Journal of Educational Psychology, 80(3), 294290.

Zimmerman, B. J., \& Schunk, D. H,. (2001). Self-regulated learning and academicachievement: Theoretical perspectives (2nd ed.). New York: Lawrence Erlbaum Associates.

Zimmerman, B. J., \& Schunk, D. H. (2007). Motivation: An essential dimension of self-regulatedlearning. In D. H. Schunk \& B. J. Zimmerman (Eds.), Motivation andself-regulated learning: Theory, research, and applications (pp. 1-30). New York: Lawrence Erlbaum Associates. 